\title{
VZPOMÍNKA NA JINDŘICHA WALDESE
}

\author{
Doc. Ing. Václav Lednický, CSc. \\ Katedra managementu a podnikání, Obchodně podnikatelská fakulta v Karviné, Slezská \\ univerzita v Opavě, Univerzitní nám. 1934/3, Karviná \\ lednicky@opf.slu.cz
}

V roce 2011 uplynulo sedmdesát let od smrti vynikajícího českého podnikatele, Jindřicha Waldese (1876 - 1941), na jehož jméno sice současná generace zapomněla, ale jim navržené a zlepšené produkty užívá. Tento dříve velmi slavný a dnes poměrně málo známý podnikatel byl ve světě v první třetině dvacátého století označován jako „světový král knoflíků “ a u nás se mu velmi často říkalo „Bat’a knoflíkü“. Nutno podotknout, že toto označení bylo na místě, nebot' se mu podařilo z pozice opravdového selfmademana téměř z ničeho vybudovat výrobní a obchodní nadnárodní společnost produkující v třicátých letech podle sdělení ŠIMONA (2) polovinu světové produkce kovových spínadel, těch nicotných drobností, které však člověkovi zpř́ijemňují život a bez nichž se velmi těžko obejde. Základem jeho nebývalého úspěchu se stal patentní knoflík, obyčejná ,patentka“, kdy spolu se spolumajitelem firmy technikem Hynkem Pucem rozvinul a prakticky zrealizoval nápad jedné spoluzaměstnankyně, jejíž jméno však již zapadlo do zapomenutí, jak vyplývá z informace HLAVÁČE (1). Velmi šikovný a možno říci téměř geniální mechanik a konstruktér Hynek Puc sestrojil jedinečnou výrobní zakládačku, která do dnešních dob nebyla překonána. A tak spojením vynikajícího mechanika Puce a skvělého obchodníka Waldese s jedinečnými manažerskými schopnostmi a za finanční podpory tř̌tího společníka firmy, Eduarda Merzingera, vzniká v roce 1902 dynamicky se rozvíjející podnik, v němž jsou uplatňovány všechny moderní americké podnikatelské, výrobní i obchodní postupy.

V roce 1907 je postavena nová továrna v pražské čtvrti Vršovice, která spolu s později založenými pobočkami v zahraničí má ve svém výrobním programu široký sortiment 750 výrobků. Nejslavnějším výrobkem se stala již dříve zmíněný módní stiskací knoflík nazvaný „Koh-i-noor“ podle největšího diamantu světa, který přinesl podniku nečekaný úspěch. Zde se projevil Waldesův smysl nejen manažerský, ale také marketingový nebot' tím, že tento patentní knoflík byl nejen významnou inovací, ale byl i nositelem skvělého reklamního symbolu. A tak dívčí hlavička s patentkou voku, se stala trvalým symbolem výrobního programu tohoto podniku do dnešních dnů a trvale udivuje svou jednoduchostí, nápaditostí a jedinečností. Později se k tomuto úspěchu s patentním knoflíkem, který neodíral látku oděvu, připojil i prodejní úspěch zdokonaleného zipu i dalších kvalitních šatních spínadel. Waldes byl totiž velmi iniciativní zlepšovatel, a jak se zmiňuje HLAVÁČ (1) vlastnil 465 patentů a drobných zlepšovacích návrhů na modernizaci výrobků nebo námětů na dopracování určité inovace. Spolu s moderní strojní výrobou byl Jindřichem Waldesem prosazován také výrazný sociální aspekt podnikání, který byl charakteristický nejen přípravou zaměstnanců ve vlastní učňovské škole, ale i péči o jejich bydlení, odborný rủst, sportovní i kulturní vyžití a další vzdělávání v oblasti jazyků, ekonomie a techniky. Velmi výrazně a trvale upozorňoval na potřebu vysokoškolského ekonomického vzdělání u podnikatelů a vedoucích pracovníků jednotlivých podniků. Vlastní manažery a perspektivní pracovníky vysílal na zahraniční stáže a pro ostatní pracovníky organizoval rekvalifikační kursy. Za velké hospodářské krize na počátku trricátých let patřil jeho podnik $\mathrm{k}$ velmi malé skupině našich podniků, které nepropustily ani jediného zaměstnance $\mathrm{z}$ práce. 
I když Waldes neměl teoretické odpovídající ekonomické vzdělání, díky svým zkušenostem, svému nadání i vysoké vrozené inteligenci patřil v meziválečném období minulého století $\mathrm{k}$ předním osobnostem hospodářského života u nás a byl považován za význačného národohospodáře. Jednou z jeho hlavních prosazovaných myšlenek byl požadavek, aby v rámci politiky státu byla zavedena státní podpora exportu i propagace Československa a jeho výrobků v zahraničí. Při té př́ležitosti nelze opomenout, že díky neúnavné snaze Jindřicha Waldese se meziválečné Pražské vzorkové veletrhy staly významnou evropskou obchodní záležitostí, které byly obchodníky vyhledávány. Zasazoval se také intenzivně i o podporu státu vynálezectví a vědeckému výzkumu, nebot' si uvědomoval obrovský význam těchto aktivit pro rozvoj průmyslu. Zároveň navrhoval zřídit instituci, která by zajistila dodržování morálního kodexu v podnikání. Své národohospodářské znalosti si rozšiřoval pravidelnými konferencemi i setkáními s americkým presidentem Delano Rooseveltem, tvůrcem zajímavého hospodářského programu pro Spojené státy třicátých let a s jeho ekonomickými poradci. Současně jako podnikatel byl průkopníkem moderního řízení podniků podle amerického vzoru, čerpal zkušenosti u Henryho Forda. Od roku 1918 začal přetvářet svůj podnik na nadnárodní společnost, která měla v zahraničí své samostatné pobočky, aby překonal celní bariéry a jiné dovozní překážky, které mezi sebou vytvářely jednotlivé státy. Na rozdíl od Tomáše Bati však nevytvořil sít' vlastních prodejen, ale podle HLAVÁČE (1) pro firmu pracovalo několik stovek samostatných obchodních zástupců.

S odstupem doby lze konstatovat, že Jindřich Waldes nejen vhodně využíval poznatků taylorismu, ale trvale jej obohacoval o nové poznatky a v souladu s vývojem znalostí i modernizoval. V jeho podniku byly uplatňovány následující vývojové řídící trendy:

- Prováděl intenzivní racionalizaci výroby cestou jak intenzivní modernizací výrobního zařízení, tak budováním prostorných, vzdušných a vkusných výrobních prostor.

- Specielní stroje vlastní konstrukce byly vyráběny v podnikové strojírenské dílně.

- Zavedl dobře promyšlený marketing, který se opíral nejen o sledování potřeb zákazníků, a dobře promyšlenou, vkusnou i nápaditou reklamou, ale i trvalým podrobným sledováním chování konkurence což mu umožňovalo rychle reagovat na módní změny v oblasti podnikatelských aktivit firmy.

- V podniku byla výrazným způsobem modernizována veškerá administrativní činnost tak, že využívala v podstatě veškeré novinky, které mohly zajistit rychlé vyřizování korespondence i potřebnou evidenci.

- Zdůrazňoval potřebu trvalé kontroly vstupních surovin, která zaručovala základní předpoklad kvalitního výrobku, a proto v podniku zř́ílil laboratoř na zkoušení kovů, která zajišt'ovala kontrolu potřebné kvality vstupů pro více než dva a půl tisíce druhů drobného kovového zboží.

Mimo to doprovázela uvedená organizační, technická a technologická zlepšení i rozsáhlá opatření sociálního charakteru kam je potřebné zařadit především:

- Zřízení Podpůrného fondu, z něhož byly vypláceny nejen příspěvky při narození dítěte, př́ispěvky $\mathrm{v}$ mateřství, při úmrtí $\mathrm{v}$ rodině, ale $\mathrm{i}$ příspěvky na otop při mimořádných zimách, příspěvky na stěhování, za věrnost k podniku, za zlepšovací návrhy. Současně byl tento fond i zdrojem půjček zaměstnanců.

- Solidní odměňování, které bylo základem dobré životní úrovně pracovníkủ podniku a stalo se základním článkem jejich sociálních jistot.

- Vybudování potřebného zázemí pracovních prostor, jimiž se staly převlékárny, šatny, umývárny a další zařízení sociálního charakteru, které byly určeny odděleně pro muže a ženy. Těmito opatřeními se tak zařadil jeho podnik mezi přední podniky ve státě. 
- Vytvoření parkové úpravy okolí podniku přispěl k zpř́ijemnění pracovního prostředí nejen pro zaměstnance, ale byl vytvořen i estetický a přitažlivý vzhled podnikového areálu pro veřejnost a tak přispěl $\mathrm{k}$ vhodné representaci této pražské čtvrti.

- Zřízení Nadace pro nemajetné studenty a válečné invalidy, kteří mohli u této nadace požádat o finanční příspěvky.

- Uvolňování finančních příspěvků značného rozsahu určených na podporu budování staveb jak náboženského tak sportovního charakteru v pražské čtvrti Vršovice, kde měl svůj podnik. Mimo to, sponzoroval stavbu památníku Jana Amose Komenského v Naardenu, o čemž se v současnosti málo neví.

I když Jindřich Waldes nevytvořil jako Tomáš Bat'u jedinečnou řídící podnikovou soustavu, patřil podle tehdejších zahraničních ohlasů k významným osobnostem československé meziválečné ekonomiky a české kultury. Za jeho hlavní odkaz budoucnosti můžeme počítat významnou podporu českých umělců a tvorbu ucelených sbírek jejich uměleckých děl. Tím ukázal potřebný směr vhodného mecenášství vytvářející základní předpoklady pro život i rozvoj řady nadaných maliřů, sochařù, sklářů i grafiků naší nově vzniklé republiky, s nimiž se často stýkal. Nejčastěji je však spojováno jméno Jindřicha Waldese se jménem malîre Františka Kupky, kdy první setkání z roku 1919 přerostlo v dlouhodobé přátelství, které trvalo devatenáct let. Toto přátelství přerušila až válka a smrt Jindřich Waldese. Při té př́ležitosti nutno zdůraznit, že Waldes se stal současně i významným mecenášem svého přítele, nebot' více než velkoryse platil svého malî́re. Tím, že shromáždil 289 Kupkových prací, jak zdůrazňuje ŠIMON (2), vytvořil ve své době jednu z nejdůležitějších světových kolekcí jednoho malîre, což umožňovalo presentovat komplexní pohled na jeho tvorbu. Za nacistické okupace jeho sbírku zachránila správa Státní sbírky starého umění v Praze, roku 1950 se pak stala součástí sbírek Národní galerie. V rámci restitučních postupů byla sbírka vrácena dědicům Jindřicha Waldese, přičemž tito významné části sbírky věnovali státu a z části prodali za solidní cenu Národní galerii.

Velmi kuriózním jeho činem bylo zřízení vlastního soukromého muzea šatních spínadel, které bylo velmi navštěvované veřejností. Sbírkový fond muzea tvořilo sedmdesát sedm tisíc předmětů a jeho součástí byl nejen archiv krojovaných obrazů ale i knihovna. Waldes totiž považoval spínání oděvů (především však knoflík) za důležitou součást národní kultury a významnou složku uměleckého projevu jednotlivých národů. Tato sbírka knoflíků je nyní součástí sbírek Městského muzea v Jablonci nad Nisou. Významnou položku soukromého muzea tvořilo 387 stř́ibrných předmětů, které byly součástí tzv. „karlštejnského pokladu“. Poklad byl po navrácení rodinou velkoryse věnován Uměleckoprůmyslovému muzeu v Praze, kde je jeho ukázka trvalou součástí expozice.

Veliký český vlastenec, významný průmyslový podnikatel, a neobvykle štědrý mecenáš českého umění poznal nebezpečí nastupujícího nacizmu i možné okupace našeho státu a včas poslal rodinu do Spojených států amerických. I když si byl vědom hrozbě, která mu hrozila pro jeho židovský původ, nejen že neopustil naší republiku, ale zapojil se do ilegálního odboje proti německým okupantům. Byl však jako osoba neprrátelská Velkoněmecké říše zatčen na podzim 1939 a po krátkém věznění na Pankráci odvlečen do Jeny a pak poslán do koncentračního tábora $\mathrm{v}$ Buchenwaldu V roce 1941 vykoupil jeho život za osm milionů předválečných korun jeho bratr Sigmund, který žil v USA (2). Během cesty lodí Jindřich Waldes zemřel asi záhy po zakotvení v Havaně a rodina obdržela pouze popel. Okolnosti jeho smrti jsou zahaleny tajemstvím, i když je asi pravdivá domněnka HLAVÁČE (1), který uvádí, že Jindřichu Waldesovi lékař nacistického doprovodu vstříknul smrtící injekci. 
Použitá literatura:

1. Hlaváč, Miroslav., M. Tvůrci českého zázraku. 1. vyd., Praha: APS Agency Praha, s.r.o., 2000, 208s., ISBN 80-86363-00-7

2. Šimon, Patrik Jindřich Waldes sběratel umění. 1. vyd.,Praha:Patrik Šimon - Eminent, 2001, 227s., ISBN 80-9025569-3-X 